\title{
TAVARES, Gonçalo M. Os velhos também querem viver. Alfragide: Editorial Caminho, 2014. 91 p.
}

\section{a}

\begin{abstract}
Em tempo de guerra quem faz mais falta: o homem que fora de casa combate ou a mulher que dentro de casa protege os filhos que mais tarde sairão de casa para combater? Não há resposta e nunca houve resposta. (TAVARES, 2014, p.9)
\end{abstract}

O prólogo e o epílogo sintetizam, em seu breve tecido, o enredo de Os velhos também querem viver, de Gonçalo M. Tavares, de modo tão simples, como se Penélope se cansasse de urdir e se rendesse, de vez, à evidência dos factos. O início solta-se de um fim, na ânsia de uma continuidade, e o fim desfaz-se, em seu conceito unívoco, resgatando-se em corpo inteiro de seu próprio começo. Na sinuosidade do mesmo, a história, em busca de sua substância, nunca se lacra. Na verdade, trata-se de uma reescrita que, recobrando da tragédia clássica o cânone do sacrifício e o esquema da separação pela Morte e da recuperação pela desnaturalização da realidade humana limitada pelos condicionalismos físicos e únicos possíveis, permite ao Autor ancorar a sua narrativa na ancestral e reiterada fórmula (mimetização literária por si mesmo denunciada) da peça Alceste de Eurípides.

Desenvolvida em extensos fios de verso não rimados, a narrativa de $O s$ velhos incide, de modo contido, sobre o doloroso e hesitante caminho de inquietação, refletindo sobre o instinto humano de se negar ao sacrifício. Neste caso: em plena década de noventa, numa praça em guerra - Sarajevo -, descem na teia da narrativa os deuses, acercando-se da História que nasce pelos e entre os homens; em seu seio, um homem, Admeto, está a morrer; porém, Apolo poderá salvá-lo se, aceitando o sacrifício, alguém morrer em seu lugar. Ante a possibilidade de se saber substituído pela entrega, quase absurda, de um outro, clama Admeto, em comum pensamento com a (des)humanidade em volta, que se ofereçam o seu pai ou a sua mãe. Todavia os dois velhos "também querem viver"; em ato último, avança a sua mulher, Alceste, e recua, no compasso inverso, a esfera gorda da humanidade.

A mitologia contraria a Morte que

perdeu a paciência

para deuses que se intrometem em assuntos

da fisiologia e do metal (TAVARES, 2014, p. 17).
- assegurando, de modo justificado, que entrando num corpo vivo não tem mais como ou porque sair. A Morte, não obstante situar-se como a consciência que não compreende, no seu gesto global, a atitude da humanidade, jamais deixa de ser, numa junção terrena, a matéria que precisa de se alimentar, em jus da sua sobrevivência. Por seu lado, Admeto transparece por inteiro em sua fragilidade e, passivamente, aceita a solução que lhe é proposta.

O Coro em corrente oscilante percorre as ruas, espreita por entre as portas entreabertas das casas, passa pelos homens: é ele os olhos e os ouvidos dos que aos sentidos se negam, embora deles inoculados. Assistindo a uma gradação do sentimento que de genuíno se torna espelho refletor da vanidade, o Coro presencia a acusação que Alceste faz aos pais de Admeto e a sua exigência para que, em troca do seu sacrifício, Admeto jure não mais deixar entrar uma mulher na sua casa.

É chegado o momento, sob pena de o objeto textual convergir numa estrutura paragrafal disseminadora, por um lado, do caos e, por outro, de um acessório da farsa humana, de na estetização do classicismo despontar a emergência de uma reviravolta que contrarie a figura estática da trama.

Entra em cena Hércules, o amigo, solicitando acolhimento e tentando perceber a razão do seu rosto quase apagado. Demorando-se na subtileza, o homem que aceitou a Morte da mulher não aprofunda o argumento, fechando a sua largueza dentro de si, como uma pequena caixa que esconde seu grande segredo dentro de um espaço maior. Assim, e sem perscrutar muito além do permissivo pressentido, o visitante "cede e fica" (TAVARES, 2014, p.49).

$\mathrm{O}$ texto segue a sua tessitura, e, como em toda a tragédia clássica, vive-se no fundo da boca de nossa leitura o corolário de um conflito, o do confronto entre Admeto e seu velho pai. Apoiando-se, sem mandamento de uma verdade, na sentença de que os velhos "sempre pareceram formas humanas / de, em plena vida, se publicitar a morte" (TAVARES, 2014, p.54), Admeto agride, pelo gesto verbal, o seu progenitor:

- Não te quero aqui! Não és bem-vindo.

Já tão velho - diz Admeto -, e não cedeste a tua vida em vez da minha. $[\ldots]$

não aceitaste por egoísmo (TAVARES, 2014, p. 53) 
A resposta faz-se retumbante e o eco exalante do tato que não chega a tocar perturba:

Se os novos gostam de viver, os velhos também. E por que razão a vida de um velho valeria menos do que a vida de alguém que agora começa? Que cálculos absurdos são esses? murmura. E por que não o contrário?

Por que não proteger a sabedoria dos muitos anos, em vez da excitação do jovem que ainda quer conhecer? Sou velho, diz Feres, e por isso quero viver! $\mathrm{E}$ tu, Admeto, és novo e por isso queres viver! $[\ldots]$

Não podes pensar que um velho

é metade de um homem

(TAVARES, 2014, p. 56).

Depois de excessos cometidos enquanto hóspede na casa enlutada, Hércules é, assim, surpreendido pelo conhecimento da sua imoralidade e, em ato purgativo, decide "resgatar Alceste. / Trazê-la de novo para o mundo e para os vivos" (TAVARES, 2014, p. 71).

A física do corpo, cingindo-o num quadro temporal delimitado, não admite, nem raramente, que o nosso marco existencial se desdobre numa continuidade estendida sem finito desgaste. Sem embargo do mesmo, quis-se em dado momento da história humana que os deuses se envolvessem entre os homens, divulgando vindouramente a sua vontade maior de contrariar o aspeto que tanto nos atemoriza: a Morte, ela mesma.

O seu dedo imperativo exigia a interrupção do ciclo natural; mas, mesmo assim, nada impediria que dele se apropriasse o escritor na demanda de um gesto simbólico redimindo-o da culpa de existir, como se a consciência além do desconhecido, e já em processo de traspassamento, fizesse de si um profanador da ordem cósmica.

A Morte questiona a vontade que procura superar-se em sua essência natural, suspendendo-a, em razão do alcance de uma quase inexistência longe da fronteira que nos atrai para a dor.

O fenómeno biológico da Morte indissocia-se de um outro fenómeno, o social, que constantemente veicula o nosso pensamento na problematização sobre a interdependência relacional, porém, sem o objetivo final de a entender, porquanto implicando uma submissão da própria individualidade e, de certo modo, a perda de algo essencial, quando em comunhão com o outro. Nesse ponto nos situa o bom entendimento com o outro. Dois seres implicam-se em comutação. Esse conflito assume-se imutável no gene histórico do homem, todo ele em eterno ruído consigo mesmo. Admeto sente o suplício possuindo-o intimamente - aceita, de imediato, que a sua mulher se outorgue responsável pela assunção da Morte em seu lugar; mas, lateralmente, culpabiliza os pais por não assumirem essa obrigação de responder por si.

Neste manifesto o homem exige que o mundo, em seu mar faminto e incessante, se subjugue à redutibilidade racional, pequena em face da inexorável irreversibilidade da naturalização. Pode, em certeza, o sacrifício ser percebido como um sofrimento inútil perante a inevitabilidade da Morte. Mesmo que outro se coloque em seu lugar, ela existe e emerge imponente. Os preceitos que em redor tentam prorrogar a sua ausência revelamse em dado momento quase ridentes em meio de tanto despropósito e desfiguramento.

A incomunicabilidade humana persiste sendo uma falha numa rocha dura e geradora de um desentendimento maior que coloca no âmago da sua problemática a futilidade do sentimento recíproco e a incerteza do seu conseguimento. $\mathrm{O}$ apego à individualidade é a ferida que vigora em todo esse quadro: o ser faz-se categoricamente para si e para a sua vivência, faz-se em crescimento interior e em isolada progressão da sua extensão, ampliando-a massivamente e apenas em retorno de si mesmo. Nesta intimidade, a Morte, sendo-lhe exterior, nega-o e, no percecionamento desse absurdo, Admeto recusa-a e acolhe quase em serena e resignada dor o controle despossuído da sua mulher. No capricho de prolongar a inteira fisicalidade, resulta em homem insuficiente, porquanto pela metade, sucumbindo ao sofrimento.

Todavia, o regresso da mulher inutilizará o sentimento de rendição e ilibará a culpa velada de Admeto, conduzindo o leitor a questionar a (i)moralidade e o fracasso do sacrifício.

Em discurso indireto, por obediência a um verso livre, Gonçalo M. Tavares resume, pois, o essencial da tragédia Alceste, de Eurípides. Os velhos também querem viver seria o primeiro objeto literário da sua, ainda parca, digressão pelo mundo mitológico. Essa, a novidade; e, dentro da novidade, a raridade: uma referência espacial (Sarajevo) em refúgio de um limite temporal (década de noventa do século XX). Porém, a brevidade de cada volume seu, a concisão do pensamento - quase uma reta numérica, com pontuais variantes disruptivas que redimem ou arguem sobre a convicção do sujeito no cosmos -, a comicidade quase dramática de tão desassossegada, na linha de um estranhamento literário formal, que caracterizam a sua já extensa obra atravessando mais que um género, mantêm-se. Nela percebe-se, sobretudo, a influência de uma introspeção tarkovskiana: formulando uma intriga aparentemente simples, o Autor enreda-nos, enquanto indivíduo no mundo, no âmago da nossa única intimidade e em desejo do questionamento da nossa existência. 
Assim, no final da nossa leitura interrogamo-nos se será este um texto de separação e esperança. Não: antes da inexistência do homem enquanto objeto inefável da sua própria vanidade.

Única leveza fica sendo o texto e este, o corpo que se regenera e renasce da cinza e em cinza. Tão seguro de insustentável e rigorosamente fundado em si, não se documenta com a inapropriação do que o transcende, desvelando-se signo superior, uma vez que semelhantemente imatérico.

SUSANA VIEIRA

CLEPUL

Recebido: 14 de junho de 2017

Aprovado: 21 de junho de 2017

Contato: susanatvieira@gmail.com 